\title{
Use of hyaluronate sodium $v$ air in extracapsular cataract extraction
}

\author{
KENYON S. KENDALL, DO
}

A total of 17 patients

underwent extracapsular cataract extraction with artificial lens implantation by one surgeon. Eight were given hyaluronate sodium (Healon) during the procedure, while nine received only air. Corneal thickness and endothelial cell counts were obtained one day prior to surgery and 90 days postoperatively. There were mean cell losses of $10.5 \%$ and $11.2 \%$ in the Healon and air groups, respectively. This is a mean difference of $0.7 \%$, which is not significant statistically. Therefore, despite several studies that demonstrate the protective value of hyaluronate sodium on the corneal endothelium during anterior segment surgery, this study showed no such difference in the protective effects between the two.

With the advent of precise techniques and instrumentation in microsurgery of the eye, there has been a surge in the number of cataract extractions with artificial lens implantation in this country. The combination of extracapsular cataract extraction and lens implantation with preservation of an intact posterior capsule has been reported to lower the incidence of postoperative cystoid macular edema and lens dislocation. Additionally, there has been a continued effort to reduce intraocular trauma and, therefore, postoperative complications. ${ }^{1}$
There have been numerous clinical studies ${ }^{2-6}$ suggesting that the use of $1 \%$ hyaluronate sodium (Healon) in cataract surgery has a potential protective effect on the corneal endothelium. The present study was undertaken to compare preoperative and postoperative endothelial cell counts while performing the same procedure using Healon in one group of patients and under air ${ }^{7,8}$ in another group.

\section{Patients and methods}

During prestudy screening, patients with a history of glaucoma, diabetes mellitus, uveitis, prior ocular trauma or surgery, or a high degree of myopia were excluded.

A total of 17 eligible study patients underwent extracapsular cataract extraction with artificial lens implantation, as performed by one surgeon. Corneal thickness and endothelial cell counts were determined one day prior to surgery and 90 days postoperatively. All patients were examined via specular microscopy..$^{9}$

Patients was assigned alternately to receive Healon prior to anterior capsulotomy and again during lens implantation (eight subjects) or to have capsulotomy lens delivery, cortical aspiration and irrigation, and lens implantation under air (nine subjects).

Prior to surgery, optimum mydriasis was achieved in all patients using $1 \%$ tropicamide and $10 \%$ phenylephrine. Local anesthesia was prepared by mixing $7.5 \mathrm{cc}$ of Marcaine with $.5 \mathrm{cc}$ of Wydase and $7.5 \mathrm{cc}$ of $2 \%$ Xylocaine. Approximately 5 to 7 cc of anesthetic was used to perform retrobulbar and facial anesthesia via the O'Brien technique. 


\begin{tabular}{|c|c|c|c|c|c|c|c|c|c|c|c|}
\hline \multicolumn{6}{|c|}{ Healon use (group 1) } & \multicolumn{6}{|c|}{ Air use (group 2) } \\
\hline Patient & Eye & $\begin{array}{c}\text { Pre- } \\
\text { operative } \\
\text { count }\end{array}$ & $\begin{array}{l}\text { Post- } \\
\text { operative } \\
\text { count }\end{array}$ & $\begin{array}{l}\text { Cell } \\
\text { loss }\end{array}$ & $\begin{array}{c}\% \\
\text { Loss }\end{array}$ & Patient & Eye & $\begin{array}{l}\text { Pre- } \\
\text { operative } \\
\text { count }\end{array}$ & $\begin{array}{l}\text { Post- } \\
\text { operative } \\
\text { count }\end{array}$ & $\begin{array}{l}\text { Cell } \\
\text { loss }\end{array}$ & $\begin{array}{c}\% \\
\text { Loss }\end{array}$ \\
\hline 1 & OD & 2,400 & 2,200 & 200 & 8.3 & 1 & OD & 3,600 & 3,300 & 300 & 8.3 \\
\hline 2 & OD & 3,000 & 2,800 & 200 & 6.7 & 2 & OS & 2,800 & 2,500 & 300 & 10.7 \\
\hline 3 & OS & 3,300 & 3,000 & 300 & 9.1 & 3 & OS & 2,300 & 2,000 & 300 & 13.0 \\
\hline 4 & OD & 3,600 & 3,000 & 600 & 16.7 & 4 & OD & 2,400 & 2,200 & 200 & 8.3 \\
\hline 5 & OS & 2,600 & 2,400 & 200 & 7.7 & 5 & OD & 2,700 & 2,400 & 300 & 11.1 \\
\hline 6 & OD & 2,600 & 2,600 & 0 & 0.0 & 6 & OS & 2,700 & 2,350 & 350 & 13.0 \\
\hline 7 & OS & 2,800 & 2,000 & 800 & 28.6 & 7 & OS & 2,800 & 2,550 & 250 & 8.9 \\
\hline \multirow[t]{3}{*}{8} & OD & 3,600 & 3,400 & $\underline{200}$ & 5.6 & 8 & OD & 2,700 & 2,400 & 300 & 11.1 \\
\hline & & & & & & 9 & OD & 3,000 & 2,500 & 500 & 16.7 \\
\hline & Totals & 23,900 & 21,400 & 2,500 & & & Totals & $2 \overline{5,000}$ & $2 \widehat{2,200}$ & $2 \overline{800}$ & \\
\hline
\end{tabular}

All patients had cardiac monitoring intraoperatively, and sedation was controlled intravenously by an anesthesiologist.

The surgical technique, with use of an automated aspiration-irrigation system, was the same for all 17 patients. A 3-mm corneoscleral incision was made. In eight patients, Healon was injected into the anterior chamber to cover the anterior surface of the lens completely. In the other nine patients, air was injected to fill the anterior chamber completely.

After anterior capsulotomy was performed, the incision was widened to $11 \mathrm{~mm}$ in all patients. For group 1 patients, Healon was again injected to fill the anterior chamber completely, while any loss of air during capsulotomy was immediately replaced by reinflation for group 2 subjects. Lens delivery was performed using a lens loop in both groups. The remaining cortical material was aspirated free from the posterior chamber. Healon was instilled into the anterior chamber and also placed onto the surface of the intraocular lens in group 1 subjects, and the anterior chamber again was reinflated with air in group 2 patients.

In both groups, lens implantation was performed with an intended placement in the capsular bag. During this aspect of the procedure, any loss or collapse of the anterior chamber was remedied immediately by reinstitution of Healon or air.

The corneoscleral incision was closed with 10-0 nylon suture in a continuous fashion. Prior to complete closure, Healon was removed from the anterior chamber with the irrigation-aspiration system or air was replaced with a balanced salt solution. All patients received $5 \mathrm{cc}$ of Garamycin subtenons preoperatively and $.5 \mathrm{cc}$ of Kefzol subconjunctivally postoperatively.

\begin{tabular}{|lccc|}
\hline \multicolumn{4}{|c|}{ TABLE 2. TOTAL ENDOTHELIAL CELL LOSS. } \\
\hline Group & $\begin{array}{c}\text { Total cell } \\
\text { loss }\end{array}$ & $\begin{array}{c}\text { \% loss of } \\
\text { original } \\
\text { cell count }\end{array}$ & $\begin{array}{c}\text { Mean cell } \\
\text { loss }\end{array}$ \\
\hline With Healon & 2,500 & $10.5 \%$ & 312.5 \\
With air & 2,800 & $11.2 \%$ & 311.0 \\
\hline
\end{tabular}

\section{Results}

Table 1 shows the preoperative and postoperative endothelial cell counts in the Healon $v$ air groups. Table 2 compares the postoperative total endothelial cell loss and percentages of loss between the two groups. The mean difference is $0.7 \%$, which is not statistically significant.

\section{Conclusions}

While this study demonstrated total cell loss within a normal range for extracapsular cataract extraction $(10.5 \%$ and $11.2 \%$, respectively), there was no significant difference in pre- and post-operative cell counts between hyaluronate sodium (Healon) $v$ air $(P<.05)$.

There is no question that protective measures should be taken to preserve the integrity of the cornea during intraocular procedures. However, with air of equal value in protecting the cornea, and given the cost-conscious environment, recommend that air be used in all stages of extracapsular cataract extraction with lens implantation.

1. Shaw El, Rao GN, Arthur EJ, et al: The functional reserve of cornea endothelium. Ophthalmology 1978;85:640-649. 
2. Kraff MC, Sanders DR, Lieberman HL: Endothelial cell loss and trauma during intraocular lens implantation: A specular microscopic study. J Am Intraocul Implant Soc 1978;4:107-109.

3. Irvine AR, Kratz RP: Endothelial damage with phacoemulsification and intraocular lens implantation. Arch Ophthalmol 1978;96:10231026.

4. Miller D, Stegmann R: Use of Na-hyaluronate in anterior segment surgery. J Am Intraocul Implant Soc 1980;6:13-15.

5. Stegmann R, Miller D: Extracapsular cataract extraction with hyaluronate sodium. Ann Ophthalmol 1982;14:813-815.

6. Miller D, Stegmann R: Use of sodium hyaluronate in human IOL implantation. Ann Ophthalmol 1981;13:811-815.

7. Dulaney DD: Effect of Healon on endothelial cell loss. Read before 1985 American-International IOL Congress, Houston, Texas.

8. Leibowitz HM, Laing RA, Sandstrom M: Corneal endothelium: The effect of air in the anterior chamber. Arch Ophthalmol 1974;92:227-230.

9. Bourne WM, Brubaker RF, O'Fallon WM: Use of air decrease endo- thelial cell loss during intraocular lens implantation. Arch Ophthalmol 1979;97:1473-1475.

10. Binkhorst CD, Mygaard P, Loons LH, et al: Specular microscopy of the corneal endothelium and lens implant surgery. Am J Ophthalmol 1978;85:587-591.

Bourne WM, Kaufman HE: Endothelial damage associated with intraocular lenses. Am J Opthalmol 1976;81:482.

Sugar J, Mitchelson J, Kraff M: Endothelial trauma and cell loss from intraocular lens insertion. Arch Ophthalmol 1978;96:449-450.

From the Department of Ophthalmology, Oklahoma Osteopathic Hospital, Tulsa.

Reprint requests to Dr. Kendall, Grand Rapids Ophthalmology, 2855 Michigan Ave, Grand Rapids, MI 49506 


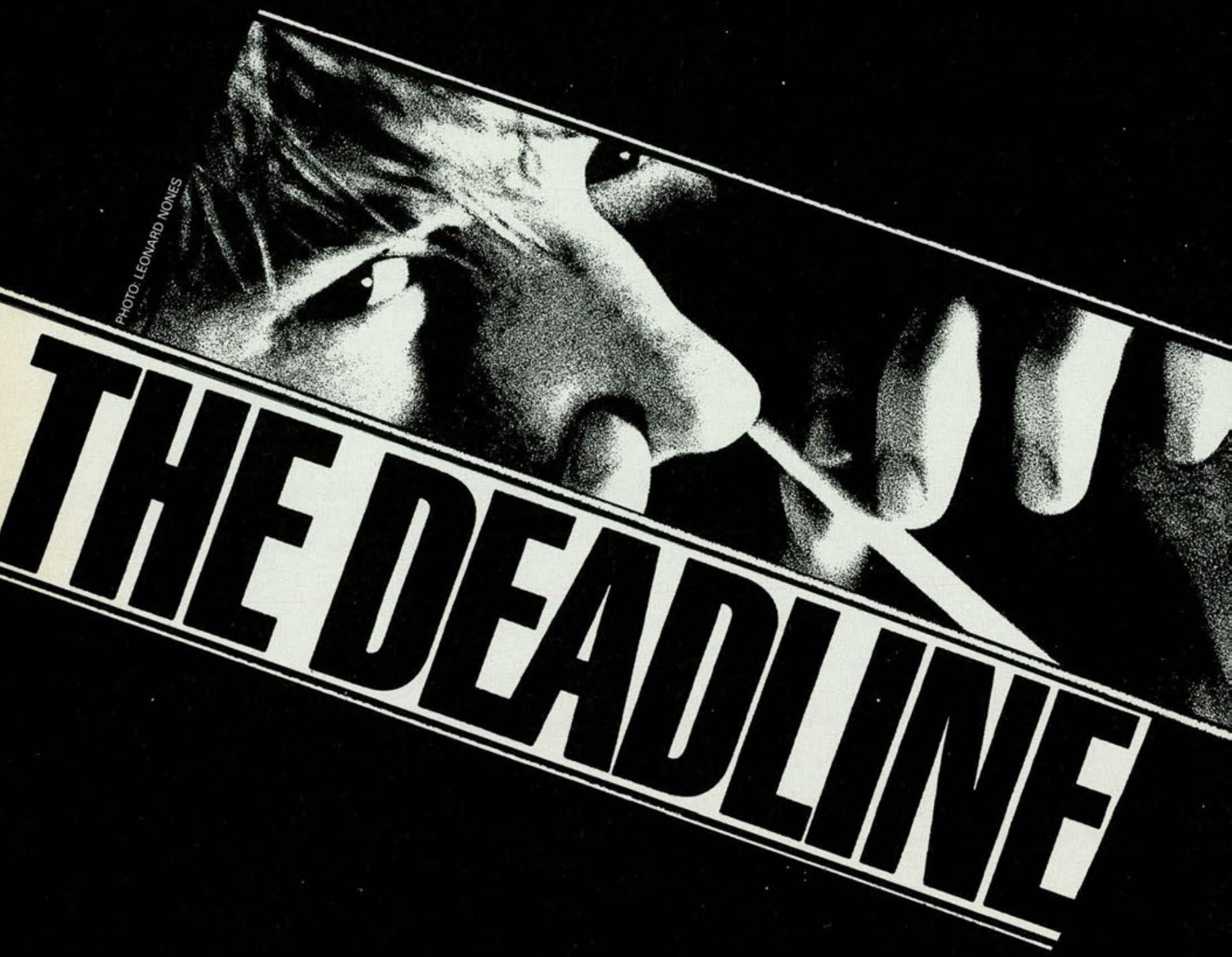

Help him beat it.

Look for drug abuse...

make it a habit.

For information and patient literature, call 1 (301) 468-2600. 